Creative Commons User Licence: CC BY-NC-ND

Abstracted by: EBSCOhost, Electronic Journals Service (EJS),

Google Scholar, Directory of Open Access Journals (DOAJ),

Journal Seek, Scientific Commons, and

Food and Agricultural Organization (FAO)
Journal of Agricultural Extension

Vol.19 (1) June, 2015

ISSN 24086851

http://journal.aesonnigeria.org

http://www.ajol.info/index.php/jae

http://dx.doi.org/10.4314.jae.v19i1.1

\title{
The Dynamics of Linkages and Innovativeness in Publicly and Privately Driven
} Agricultural Value Chains

\author{
Seth Awuku Manteaw ${ }^{1}$, J.N.Anaglo ${ }^{2}$, S D Boateng ${ }^{2}$ \\ ${ }^{1}$ Council for Scientific and Industrial Research-Ghana \\ ${ }^{2}$ Department of Agricultural Extension \\ University of Ghana
}

\begin{abstract}
The study examined how linkages among actors in the cocoa and pineapple value chains relate to the innovativeness of actors in the chains. The study showed that a policy environment that promoted public sector leadership in value chain functions and service provision, tended to offer less incentives for smallholder producers in the value chain to forge linkages and interact horizontally or vertically. It concluded that actors in agricultural value chain could build their capacity to respond to challenges if they united their efforts. In terms of policy implication, the study makes a case for more private sector involvement in value chain functions and service provision as it is more likely to foster linkages towards systems innovation.
\end{abstract}

Key words: Linkages, Innovativeness, Publicly and Privately Driven Agricultural Value Chains,

\section{Introduction}

Ghana's efforts at diversifying her export sector demand the exploitation of opportunities available in the agricultural sector. It is the strong belief that for agricultural export commodity industries such as the cocoa and pineapple to become competitive, actors in these industries, whichever level in the value chain they find themselves, must develop the capacity to respond to challenges by exhibiting innovativeness in whatever form it manifests itself. Industry actors ought to evolve means and mechanisms to ensure the growth of the industry. This paper takes its point of departure from the school of thought that innovativeness of agricultural industries is critical for countries such as Ghana to attain the desired level of economic and social development. Innovation has always played an important role in the economic development of most countries, and they are likely to become even more important in the future as the world faces new constraints to growth from population ageing (Business Council of Australia, 2006). It is therefore important that innovation, as a concept, is fully understood, especially as it relates to the agricultural sector, so that it will be possible to properly identify and encourage innovations at all levels in the agricultural commodity value chain such as production, input supplying, processing and marketing.

The literature on agricultural development has focused attention on various models of ensuring innovation. A number of ideas have emerged, especially concerning the best model that will give 
Creative Commons User Licence: CC BY-NC-ND

Abstracted by: EBSCOhost, Electronic Journals Service (EJS),

Google Scholar, Directory of Open Access Journals (DOAJ),

Journal Seek, Scientific Commons, and

Food and Agricultural Organization (FAO)

optimum returns and guarantee the kind of innovativeness that will make agricultural industries much more competitive. The debate started from linear models of innovation exemplified in the
Journal of Agricultural Extension

Vol.19 (1) June, 2015

ISSN 24086851

http://journal.aesonnigeria.org

http://www.ajol.info/index.php/iae

Technology Supply Push Model (Roling, 2010; Miller \& Cox, 2006; Rogers, 2003; Clark et al., 2003) and the Market Propelled or Induced Model (Roling, 2010; Roling et al., 2004; Evenson et al., 1979; Hayami \& Cochrane, 1971) then to a long debate on Farmer-driven Innovation (Millar, 2005; Roling et al., 2004; Rey \& Water Bayer, 2001; Van de Ploeg \& Long, 1994) and participatory approaches such as the Participatory Technology Development Model (Roling, 2010; Kotler \& Andrease, 2003; Campbell \& Salagrama, 2000; Biggs, 1989; Chambers \& Jiggins, 1987). The discussion has taken a new dimension to an Interactive Model of Innovation and more recently, to Innovation Systems Perspective and Convergence of Sciences (Spielman et al., 2009; Hall et al., 2006; Van Huis et al., 2005; Leeuwis, 2004; Nederlof, 2006). The debate seems to be gathering more momentum as we move towards an increasingly globalised economy. However, in spite of the amount of work done in the area of innovation studies and innovativeness, in particular, the fact remains that forces working for and against innovative activities in the agricultural sector are far from being fully understood.

This paper explores how the innovation systems analytical framework can be used to study two important commodity value chains in Ghana's economy, cocoa and pineapple, in an attempt to understand how linkages between and among actors in an agricultural commodity value chain can engender innovativeness, conceptualised as the capacity of actors to respond to challenges in the chain. Specifically, the paper adopts the methodological framework for the agricultural innovation system developed by Hall et al. (2006), which proposes that the capacity for continuous innovation in a given agricultural commodity value chain is a function of linkages, working practices and policies that promote knowledge flow and learning among all actors within the chain. Using the multiple case study design approach, the study examined the cocoa and pineapple value chains in Ghana with a view to gaining in-depth understanding of how the policy environment promoting public or private sector leadership in an agricultural industry influences the nature of linkages and in particular, reflects on ways in which actors show evidence of innovativeness in agricultural commodity value chains.

The purposeful selection of the two commodity value chains is to provide a basis for comparison of the public and private sector driven commodity industries and how linkages influence the overall innovativeness of actors of the two commodity value chains. The activities of the two agricultural commodity value chains, cocoa and pineapple, are largely driven by the public and private sectors respectively.

\section{Innovation as a Concept}

Innovation is often looked at in a rather isolated and mainly technical way. However, according to Leeuwis (2004), innovation must be looked at in a wider sense. He explains that a new plough, for example, is not just a new way of turning the soil, as it is likely to be effective only in conjunction with other factors such as agronomic changes (e.g. a new maize variety), new forms of social organisation with the family and new arrangements for the provision of inputs. The innovation 
Creative Commons User Licence: CC BY-NC-ND

Abstracted by: EBSCOhost, Electronic Journals Service (EJS),

Google Scholar, Directory of Open Access Journals (DOAJ),

Journal Seek, Scientific Commons, and

Food and Agricultural Organization (FAO)
Journal of Agricultural Extension

Vol.19 (1) June, 2015

ISSN 24086851

http://journal.aesonnigeria.org

http://www.ajol.info/index.php/jae

therefore affects the farming system in its entirety. On the basis of this, Leeuwis (2004, p141) looks at innovation as "a package of new social and technical arrangements and practices that implies new forms of coordination within a network of interrated actors."

A key concept that emerges from the discussion of innovation is "learning". Learning and innovation are two concepts that cannot be separated as there may be an element of learning in any innovative act. Lundvall (1992) emphasises the point that the everyday learning experiences and activities of engineers, sales representatives and other employees, as well as customers, make important contributions to innovations. Such learning, according to Lundvall (1992), is the most intense where economic actors interact; therefore, innovation is strongly embedded in the prevailing economic structure, which largely determines what is going to be learned and where innovations are going to take place. Roseboom (2004) identifies four broad categories of learning and knowledge accumulation that help to shape innovation processes:

1) Learning as joint product with other activities involving the production and use of technology ("Learning by Doing" as cited by Arrow, 1992).

2) Learning as a result of using a product, which feeds back into product design and development ("Learning by Using as cited by Rosenberg, 1982).

3) Learning as a result of interaction with other organisations (Learning by Interacting as cited by Lundvall, 1992).

4) Learning as a result of a formal discovery process, typically organised around directed $R \& D$ programmes.

All these four learning processes, according to Roseboom (2004), usually operate together, although their relative importance varies between firms, industries, and economies as well as through time.

Spielman et al. (2009), also define innovation as anything new successfully introduced into an economic or social process. In other words, they perceive innovation as not just trying something new, but successfully integrating a new idea or product into a process that includes technical, economic and social components. Going by this definition, Spielman et al. (2009) identify three important features that must not be lost on any attempt to discuss innovation. First, innovation is the creative use of different types of knowledge in response to social or economic needs and opportunities (OECD, 1999). This view draws the discussion closer to the main theme that drives this paper; innovativeness of agricultural commodity industries. To be able to survive the competition in the industry and thus become competitive, actors in agricultural commodity industries must build the capacity to respond to social or economic needs and opportunities in the industry.

The second implication of the definition of innovation offered by Spielman et al. (2009) is that a trial only becomes an innovation when it is adopted as part of a process; many agents try new things, but few of these trials yield practices or products that improve what is already in use. 
Creative Commons User Licence: CC BY-NC-ND

Abstracted by: EBSCOhost, Electronic Journals Service (EJS),

Google Scholar, Directory of Open Access Journals (DOAJ),

Journal Seek, Scientific Commons, and

Food and Agricultural Organization (FAO)
Journal of Agricultural Extension

Vol.19 (1) June, 2015

ISSN 24086851

http://journal.aesonnigeria.org

http://www.ajol.info/index.php/iae

Third, innovations are accepted as such in specific social and economic environments (Bailey and Ford (2003). Ekboir et al. (2002) buttresses this point of view with the illustration that a sighting pole at the end of a plot is an innovation for a small-scale Ghanaian farmer, because it helps the farmer to plant in straight lines, however, a new method for sequencing DNA is not an innovation, since the farmer has no use for these high-tech methods. The understanding therefore is that a new method can qualify as an innovation when it finds expression in immediate application for the benefit of the ultimate end-users.

\section{Agricultural Innovation System}

The application of the innovation systems concept in agriculture can be traced to the National Innovation System (NIS) that Freeman (1987) applied to the industrial sector of the developed economies; the multiple source of innovation models for agricultural research and technology promotion as suggested by Biggs (1989); and the inadequacy of the linear model to explain the actual process of innovation in the real world (Anandajayasekeram \& Gebremedlin, 2009). Concerning the capacity of research systems to revive the agricultural sector, Rajalahti, Woelcke, and Rehu (2005) note that strengthened research systems may increase the supply of new knowledge and new technologies, but they may not necessarily improve the capacity for innovation throughout the agricultural sector. It is against this background that the emphasis is now being placed on the Agricultural Innovation System (AIS). The AIS thinking has become an increasingly applied analytical framework to analyze technological, economical and institutional change in agriculture (Klerks et al., 2010). In the AIS approach, innovation is considered the result of a process of networking and interactive learning among a heterogeneous set of actors, such as farmers, input suppliers, traders, processors, researchers, extensionists, government officials and civil society organisations (Leeuwis, 2004, Hall et al., ～，2006, Roling, 2009).

Spielman et al. (2009) note that the AIS approach emphasises that agricultural innovation is not just about new technologies, but also about institutional change; it requires alternative ways of organising, for example markets, labour, land tenure and distribution of benefits. Given the interaction between heterogeneous actors, related to the several dimensions of agricultural innovations, it has been noted that AIS can be regarded as Complex Adaptive Systems, defined as self-organising systems "whose properties cannot be analysed by studying its component separately $\{\ldots$.$\} formed by many agents of different types, where each defines his/her strategy,$ reacts to the actions of other agents and to change in the environment, and tries to modify the environment in ways that fit his/her goals" (Spielman et al., 2009. p400).

The AIS concept emerged following the inability of other system-based approaches to promote agricultural innovation in view of the top-down and linear nature of such approaches. Different approaches to promoting agricultural innovations have emerged since the 1980s. The period before the mid 1980s was characterised by emphasis on the creation of national agricultural research systems (NARS) to strengthen research at the national level and encourage technology transfer and inventions. In the 1990s, the NARS approach changed to the pluralistic Agricultural Knowledge and Information Systems (AKIS), which Roling (1992) define as the articulated sets of actors, networks and organisations expected or managing to work synergically to support 
Creative Commons User Licence: CC BY-NC-ND

Abstracted by: EBSCOhost, Electronic Journals Service (EJS),

Google Scholar, Directory of Open Access Journals (DOAJ),

Journal Seek, Scientific Commons, and

Food and Agricultural Organization (FAO)
Journal of Agricultural Extension

Vol.19 (1) June, 2015

ISSN 24086851

http://journal.aesonnigeria.org

http://www.ajol.info/index.php/jae

knowledge, which improves the correspondence between knowledge and environment and/or control provided through technologies used in a given domain of human activity. What this means is that AKIS represents a radical policy shift from strengthening research or extension institutions (within the framework of NARS) to strengthening linkages and communication that should take place among system actors. Besides, AKIS emphasises greater client participation and financing, technology adoption and adaption and knowledge exchange mechanism (World Bank, 2009). The AKIS concept also emerged as a response to the challenges of Everett Rogers' theory of adoption and diffusion of innovations, which was preoccupied with studying why and how people come to adopt or not adopt new agricultural innovations and practices (Leeuis, 2004). The concept was developed by Roling as a diagnostic framework that helped to discern the organisational forms that enabled or constrained knowledge processes such as generation, dissemination and use of knowledge and information. An AKIS integrates farmers, agricultural educators, researchers and extensionists to harness knowledge and information from various sources for improved livelihood, and farmers are at the heart of this knowledge triangle (World Bank, 2004).

The AIS is thus a more recent approach coming after the inability of the NARS and AKIS systembased concepts to promote agricultural innovations in a more effective manner. Thus, while NARS and AKIS frameworks made critical contributions to the study of technological change in agriculture, they are now being challenged by the changing and increasingly globalised context in which sub-Sahara African agriculture is involving ( World Bank, 2006). This includes trends such as the rapid growth of markets as the main driver of technological change; new demographic and agro-ecological pressures, new economic regimes such as trade liberalisation and regional trade integration, the growth of private investment and ownership of knowledge, information and technology, and expansion of technology as a means of rapidly exchanging knowledge and information (Spielman et al., 2009).

The AIS concept therefore offers a more flexible framework for studying innovation processes in the agricultural sector. The AIS framework, according to Spielman et al. (2009), makes use of individual and collective absorptive capabilities to translate information and knowledge into a useful social or economic activity in agriculture. It requires an understanding of how individual and collective capabilities are strengthened and how these capabilities are applied in agriculture.

In recent times, Hall et al. (2006) has attempted to describe the basis hypothesis of the methodological framework for the agricultural innovation systems as follow: the capacity for continuous innovations is a function of Linkages, Working Practices and Policies that promote knowledge flow and learning among all actors within the agricultural sector. This methodology, according to Hall et al. (2006), is not, however, interested only in identifying the links or missing links in the system, but to go beyond that and impact the relationship further to analyse the underpinning causes of its impact on the system. The paper borrows Hall et al. (2006) methodological framework as the basis for the conceptual framework. According to Hall et al. (2006), the AIS framework 
Creative Commons User Licence: CC BY-NC-ND

Abstracted by: EBSCOhost, Electronic Journals Service (EJS),

Google Scholar, Directory of Open Access Journals (DOAJ),

Journal Seek, Scientific Commons, and

Food and Agricultural Organization (FAO)
Journal of Agricultural Extension

Vol.19 (1) June, 2015

ISSN 24086851

http://journal.aesonnigeria.org

http://www.ajol.info/index.php/jae

- Focuses on innovation, which is the driving force behind the study; the ability of actors in a commodity value chain to respond to difficult situations in the chain through technical, organisational and institutional innovations.

- Emphasises linkages, networks, partnership among value chain actors, through which actors build the capacity to respond effectively to difficult situations and challenges in the industry.

- Stresses new actions and new roles

- Emphasises the role of institutions, private and public, formal and informal, which support the innovativeness of agricultural commodity value chains.

- Focuses on the role of policies that inhibit or promote the innovativeness of commodity value chains

- Highlights on the inclusion of stakeholders.

\section{Methodology}

The study was generally conducted nation-wide; however, the Eastern Region of Ghana (shown in Figure 1) was purposively selected as the information-rich location. The Eastern Region is an important cocoa and pineapple production area of Ghana. It is acknowledged by cocoa scientists (Appiah et al., 1997; Ahenkorah et al., 1987) that the Eastern Region has the best soils and other environmental requirements for cocoa. Out of the five cocoa growing regions in the country (Western, Ashanti, Eastern, Brong Ahafo and Volta), the Eastern Region, based on figures from the Ghana Cocoa Board as of the 2009/2010 cocoa season, occupied the fourth position in terms of production figures, after Western, Ashanti, and Brong Ahafo. Historically, cocoa cultivation in the country started from the Eastern Region where Tetteh Quarshie, a native of Osu, Accra after returning from Fernado Po with Amelonado cocoa pods in 1879, established a cocoa farm at Akuapem Mampong. 


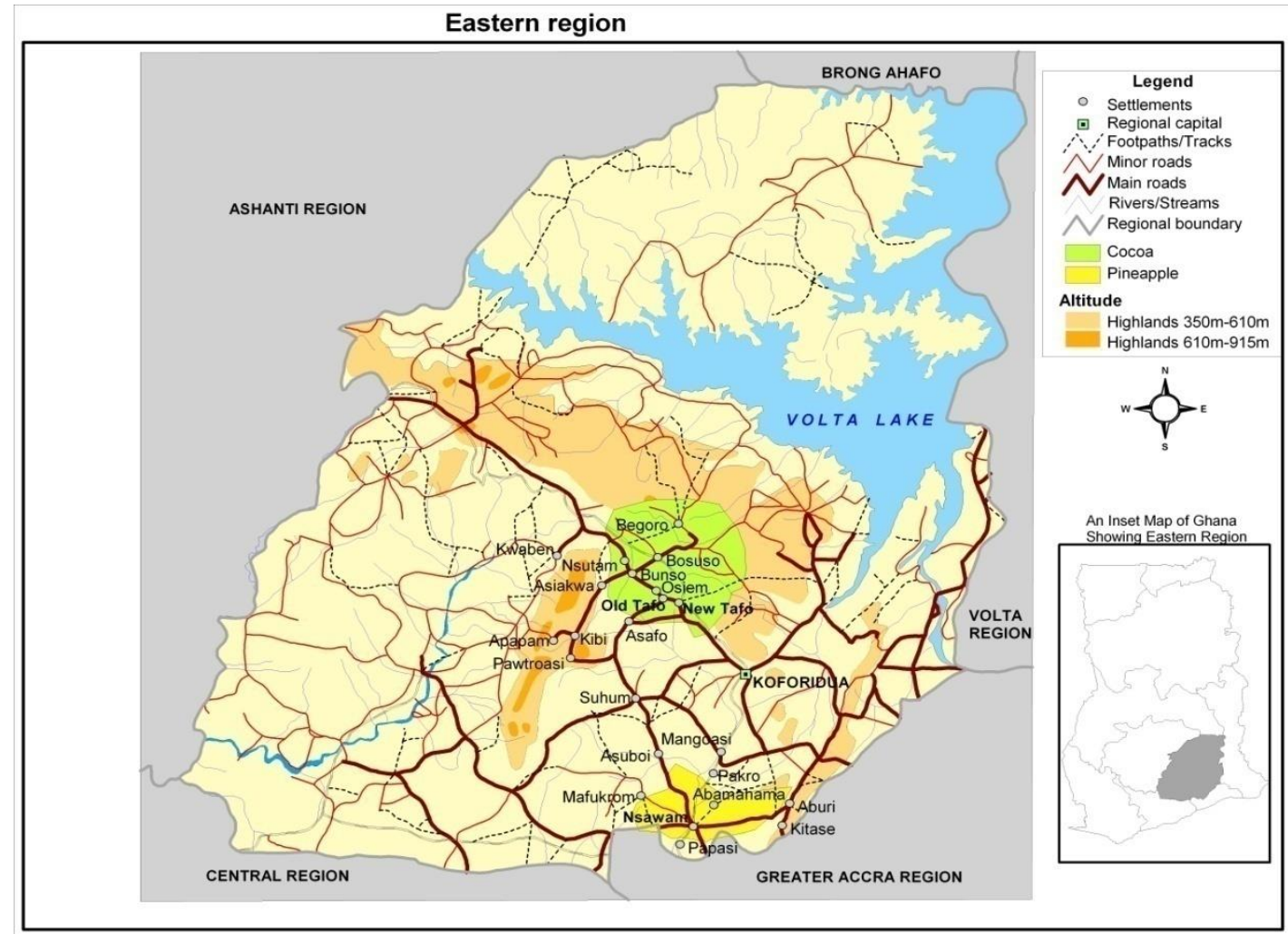

Source: Thematic Mapping Division, CSIR-INSTI, Accra, 2010

Figure 1: Map of Ghana showing the Eastern Region with the two districts

In terms of pineapple, there are three main pineapple growing geographical regions producing especially for the export market; namely, Eastern, Central and Volta regions, with marginal production from the Ashanti, Western and Greater-Accra regions. Of the three main regions, Eastern Region is the leading pineapple growing area.

Two districts of the Eastern Region were purposely selected as the specific information-rich locations for the study. With regard to pineapple, the Akuapem South District was selected, while the Tafo Cocoa District was the focus for cocoa. Besides reviewing secondary sources including, official documents on cocoa and pineapple, the study used qualitative and quantitative methods to generate primary data. The study carried out eight focus group discussion sessions (four with small-scale pineapple farmers and four with small-scale cocoa farmers) in the two respective study locations. 
Creative Commons User Licence: CC BY-NC-ND

Abstracted by: EBSCOhost, Electronic Journals Service (EJS),

Google Scholar, Directory of Open Access Journals (DOAJ),

Journal Seek, Scientific Commons, and

Food and Agricultural Organization (FAO)
Journal of Agricultural Extension

Vol.19 (1) June, 2015

ISSN 24086851

http://journal.aesonnigeria.org

http://www.ajol.info/index.php/jae

Table 1: Data Gathering Methods

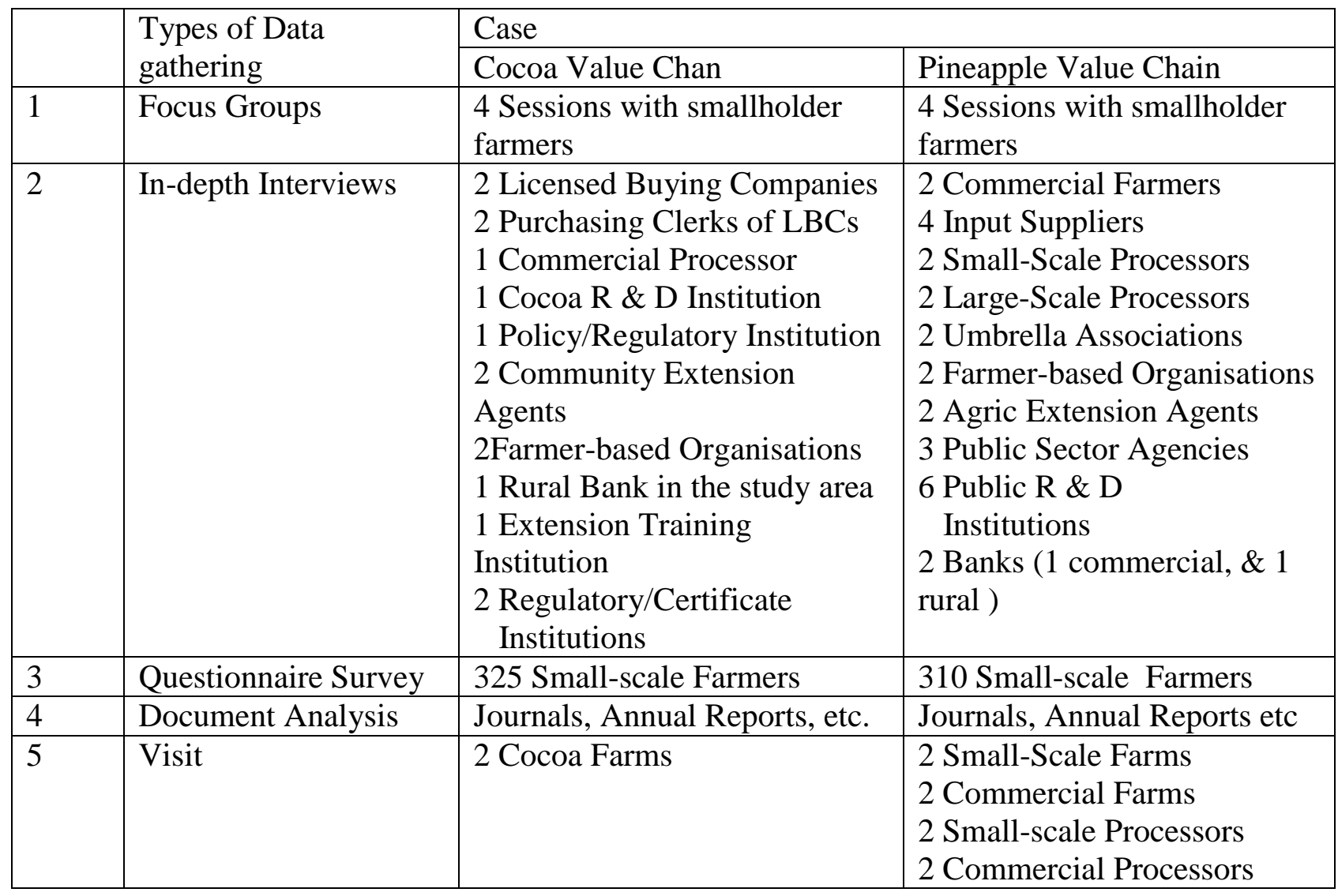

Source: Fieldwork, (2011)

The study held in-depth oral interview sessions with value chain actors (chain of actors who deal directly with the product i.e. input suppliers, farmers, buyers and processors); service providers

(the services provided by various actors who never directly deal with the product, but whose services add value to the product i.e. cocoa and pineapple research institutions, extension institutions, certification institutions); and value chain influencers (the regulatory framework, policies, infrastructure etc). Additionally, the study administered structured questionnaires to a sample size of 325 small-scale cocoa farmers in the Tafo Cocoa District and 310 small-scale pineapple farmers in the Akuapem South District. A detailed outline (Table 1) of the data gathering methods is presented.

Qualitative data (from the focus group and in-depth interview sessions) were analysed through the development of case description. A descriptive framework for organising the two case studies was developed for the case study write-ups. Two types of analysis: Within Case Analysis and Cross Case Analysis. For the quantitative data (survey of small-scale pineapple and cocoa farmers using 
Creative Commons User Licence: CC BY-NC-ND

Abstracted by: EBSCOhost, Electronic Journals Service (EJS),

Google Scholar, Directory of Open Access Journals (DOAJ),

Journal Seek, Scientific Commons, and

Food and Agricultural Organization (FAO)
Journal of Agricultural Extension

Vol.19 (1) June, 2015

ISSN 24086851

http://journal.aesonnigeria.org

http://www.ajol.info/index.php/jae

structured questionnaires), the windows version of SPSS 17.0 was used as the tool for analysis. Analysis was largely univeriate and carried out by way of descriptive statistics (frequencies and percentages).

\section{Results and Discussions}

The results are presented in two parts: (1) value chain linkages from the perspectives of smallscale cocoa and pineapple farmers in the two study locations (based on the survey of small-scale cocoa and pineapple farmers using structured questionnaires) (2) Discussion of how value chain linkages, horizontally and vertically, have engendered innovativeness among actors in the cocoa and pineapple value chains.

\section{Value Chain Linkages}

The case studies showed that linkages really did exist among actors in the cocoa and pineapple value chains, and these linkages largely found expression horizontally (as in for instance, farmerbased association or cooperatives) and vertically (as in for instance, farmers' association with other value chain actors i.e. input suppliers, buyers, processors, and other 'non-actors' such as researchers, extensionists, NGOs, civil society organisations etc).

Table 2: Farmers' perceptions of linkages within the cocoa and pineapple value chains

\begin{tabular}{|l|l|l|l|l|}
\hline \multirow{2}{*}{ Nature of Linkage } & Cocoa & Pinapple \\
\cline { 2 - 5 } & Frequency & $\%$ & Frequency & $\%$ \\
\hline Farmer-to-Farmer & 144 & 42 & 296 & 96 \\
\hline Farmer-to-Input Supplier & 147 & 43 & 257 & 83 \\
\hline Farmers-to-Buyer & 144 & 42 & 276 & 89 \\
\hline Farmers-to-Processor & 141 & 41 & 280 & 90 \\
\hline
\end{tabular}

Fieldwork, (2011)

Farmers in the two respective study locations perceived such linkages to be more prominent in the pineapple value chain than the cocoa value chain as represented in table 2 . In terms of the formality of the linkages, farmer-to-farmer linkages were observed to be largely formal, while linkages with other value chain actors such as input suppliers, processors and buyers were observed to be either informal or semi-formal as shown in table 3. 
Creative Commons User Licence: CC BY-NC-ND

Abstracted by: EBSCOhost, Electronic Journals Service (EJS),

Google Scholar, Directory of Open Access Journals (DOAJ),

Journal Seek, Scientific Commons, and

Food and Agricultural Organization (FAO)
Journal of Agricultural Extension

Vol.19 (1) June, 2015

ISSN 24086851

http://journal.aesonnigeria.org

http://www.ajol.info/index.php/jae

Table 3: Formality of farmers' linkages with value chain actors

\begin{tabular}{|c|c|c|c|c|c|c|c|c|c|c|c|c|}
\hline \multirow{4}{*}{ Nature of Linkage } & \multicolumn{6}{|c|}{ Cocoa } & \multicolumn{6}{|c|}{ Pineapple } \\
\hline & \multicolumn{6}{|c|}{ Formality } & \multicolumn{6}{|c|}{ Formality } \\
\hline & \multicolumn{2}{|c|}{ Formal } & \multicolumn{2}{|c|}{ Informal } & \multicolumn{2}{|c|}{$\begin{array}{l}\text { Semi } \\
\text { Formal }\end{array}$} & \multicolumn{2}{|c|}{ Formal } & \multicolumn{2}{|c|}{ Informal } & \multicolumn{2}{|c|}{$\begin{array}{l}\text { Semi } \\
\text { Formal }\end{array}$} \\
\hline & Freq. & $\%$ & Freq. & $\%$ & Freq. & $\%$ & Freq. & $\%$ & Freq. & $\%$ & Freq. & $\%$ \\
\hline Farmer-to-Farmer & 90 & 60 & 44 & 29 & 16 & 11 & 290 & 93 & 6 & 2 & 14 & 5 \\
\hline $\begin{array}{l}\text { Farmer-to-Input } \\
\text { Supplier }\end{array}$ & 26 & 18 & 61 & 41 & 60 & 41 & 31 & 12 & 196 & 76 & 30 & 12 \\
\hline Farmer-to-Buyer & 54 & 36 & 64 & 43 & 32 & 21 & 233 & 75 & 43 & 14 & 34 & 11 \\
\hline Farmers-to-Processor & 12 & 8 & 87 & 62 & 42 & 30 & 62 & 22 & 215 & 77 & 3 & 1 \\
\hline
\end{tabular}

Source: Fieldwork, (2011)

Notes: Formal: Hold official meetings; have a constitution binding the linkage, memorandum of understanding governing the linkage. Informal: Absence of official platform for the linkage.

Semi-formal: Formal platform present, but weak

Generally, cocoa and pineapple farmers join associations for several reasons. The formation of such associations is usually premised on the need for farmers to unite their efforts and articulate their concerns with one common voice. However, a dominant source of motivation that emerged during the focus group discussion sessions with small-scale cocoa and pineapple farmers centred on the need to meet a key condition to benefit from facilities from governmental and nongovernmental organisations. For instance, for the rural banks, it would be much easier for them to advance credit to farmers in groups rather than individuals; a situation which served as a major motivation for farmers to forge horizontal linkages by way of farmer-based organization (FBOs). The formalisation of these linkages was observed to enhance their authoritativeness and authenticity, which explained the formality of farmer-to-farmer linkages compared with linkages with other value chain actors. Although not all cocoa communities in the study area had FBOs, the focus group sessions showed that cocoa farmers were increasingly realising the importance of 
Creative Commons User Licence: CC BY-NC-ND

Abstracted by: EBSCOhost, Electronic Journals Service (EJS),

Google Scholar, Directory of Open Access Journals (DOAJ),

Journal Seek, Scientific Commons, and

Food and Agricultural Organization (FAO)
Journal of Agricultural Extension

Vol.19 (1) June, 2015

ISSN 24086851

http://journal.aesonnigeria.org

http://www.ajol.info/index.php/jae

FBOs, leading to a growing trend towards farmer group formation with the facilitation and support of community extension agents.

In terms of the strength of these linkages, pineapple farmers perceived linkages among themselves as well as with other value chain actors to be stronger than cocoa farmers as shown in Table 4. In view of the rather limited involvement of the public sector in the pineapple value chain as compared with the cocoa value chain, the study showed stronger desire on the part of pineapple farmers to forge linkages and interact more strongly horizontally and vertically. These linkages had largely made service provision (e.g. extension services delivery) to the pineapple value chain more demand-driven and more pluralistic.

Table 4: Strength of farmers' linkages with value chain actors

\begin{tabular}{|c|c|c|c|c|c|c|c|c|c|c|c|c|}
\hline \multirow{4}{*}{ Nature of Linkage } & \multicolumn{6}{|c|}{ Cocoa } & \multicolumn{6}{|c|}{ Pineapple } \\
\hline & \multicolumn{6}{|c|}{ Strength } & \multicolumn{6}{|c|}{ Strength } \\
\hline & \multicolumn{2}{|c|}{ Very Strong } & \multicolumn{2}{|c|}{ Strong } & \multicolumn{2}{|l|}{ Weak } & \multicolumn{2}{|c|}{ Very Strong } & \multicolumn{2}{|c|}{ Strong } & \multicolumn{2}{|l|}{ Weak } \\
\hline & Freq. & $\%$ & Freq. & $\%$ & Freq. & $\%$ & Freq. & $\%$ & Freq. & $\%$ & Freq. & $\%$ \\
\hline Farmer-to-Farmer & 92 & 61 & 43 & 29 & 15 & 10 & 151 & 51 & 139 & 47 & 6 & 2 \\
\hline Farmer-to-Input Supplier & 0 & 0 & 72 & 49 & 75 & 51 & 0 & 0 & 127 & 49 & 130 & 51 \\
\hline Farmer-to-Buyer & 5 & 3 & 84 & 56 & 61 & 41 & 120 & 43 & 134 & 49 & 22 & 8 \\
\hline Farmers-to-Processor & 0 & 0 & 40 & 28 & 101 & 72 & 8 & 3 & 267 & 95 & 5 & 2 \\
\hline
\end{tabular}

Source: Fieldwork, (2011)

Notes: Very strong: Meet at least once every month. Strong: Meet at least once every two months. Weak: Meet at least two times in a year 
Creative Commons User Licence: CC BY-NC-ND

Abstracted by: EBSCOhost, Electronic Journals Service (EJS),

Google Scholar, Directory of Open Access Journals (DOAJ),

Journal Seek, Scientific Commons, and

Food and Agricultural Organization (FAO)
Journal of Agricultural Extension

Vol.19 (1) June, 2015

ISSN 24086851

http://journal.aesonnigeria.org

http://www.ajol.info/index.php/jae

Cocoa and pineapple farmers derive diverse benefits from linkages they establish among themselves and also with other value chain actors. For farmer-to-farmer linkages, the benefits from the perceptions of farmers had been largely for information sharing as shown in Table 5a.

Table 5a: Purpose of farmer-to-farmer Linkages in the cocoa and pineapple value chains

\begin{tabular}{|c|c|c|c|c|c|c|c|c|c|c|c|c|}
\hline \multirow{3}{*}{ Nature of Linkage } & \multicolumn{6}{|c|}{ Cocoa (Purpose) } & \multicolumn{6}{|c|}{ Pineapple (Purpose) } \\
\hline & \multicolumn{2}{|c|}{$\begin{array}{l}\text { Info } \\
\text { Sharing }\end{array}$} & \multicolumn{2}{|c|}{$\begin{array}{l}\text { Solving } \\
\text { Challenges }\end{array}$} & \multicolumn{2}{|c|}{$\begin{array}{l}\text { For } \\
\text { Inputs }\end{array}$} & \multicolumn{2}{|c|}{$\begin{array}{l}\text { Info } \\
\text { Sharing }\end{array}$} & \multicolumn{2}{|c|}{$\begin{array}{l}\text { Solving } \\
\text { Challenges }\end{array}$} & \multicolumn{2}{|c|}{ For Inputs } \\
\hline & Freq. & $\%$ & Freq. & $\%$ & Freq. & $\%$ & Freq. & $\%$ & Freq. & $\%$ & Freq. & $\%$ \\
\hline Farmer-to-Farmer & 105 & 70 & 21 & 14 & 24 & 16 & 211 & 71 & 85 & 29 & 0 & 0 \\
\hline
\end{tabular}

Source: Fieldwork, (2011)

In terms of farmer-to-buyer linkages, while such linkages were observed to be driven by the opportunity offered to sell produce, the study showed that some cocoa farmers perceived such linkages to offer the platform for information sharing as shown in Table 5b.

Table 5b: Purpose of farmer-to-buyer linkages

\begin{tabular}{|c|c|c|c|c|c|c|c|c|c|c|c|c|}
\hline \multirow{4}{*}{ Nature of Linkage } & \multicolumn{6}{|c|}{ Cocoa } & \multicolumn{6}{|c|}{ Pineaaple } \\
\hline & \multicolumn{6}{|c|}{ Purpose } & \multicolumn{6}{|c|}{ Purpose } \\
\hline & \multicolumn{2}{|c|}{$\begin{array}{l}\text { Info } \\
\text { Sharing }\end{array}$} & \multicolumn{2}{|c|}{$\begin{array}{l}\text { Solving } \\
\text { Challenges }\end{array}$} & \multicolumn{2}{|c|}{$\begin{array}{l}\text { Selling } \\
\text { Produce }\end{array}$} & \multicolumn{2}{|c|}{$\begin{array}{l}\text { Info } \\
\text { Sharing }\end{array}$} & \multicolumn{2}{|c|}{$\begin{array}{l}\text { Solving } \\
\text { Challenges }\end{array}$} & \multicolumn{2}{|c|}{$\begin{array}{l}\text { Selling } \\
\text { Produce }\end{array}$} \\
\hline & Freq. & $\%$ & Freq. & $\%$ & Freq. & $\%$ & Freq. & $\%$ & Freq. & $\%$ & Freq. & $\%$ \\
\hline Farmer-to-Buyer & 61 & 41 & 27 & 18 & 62 & 41 & 2 & 1 & 4 & 2 & 270 & 97 \\
\hline
\end{tabular}

Source: Fieldwork, (2011)

On the other hand, whereas almost all pineapple farmers perceived their linkages with processors to be motivated largely by the desire to provide a platform to sell their highly perishable 
Creative Commons User Licence: CC BY-NC-ND

Abstracted by: EBSCOhost, Electronic Journals Service (EJS),

Google Scholar, Directory of Open Access Journals (DOAJ),

Journal Seek, Scientific Commons, and

Food and Agricultural Organization (FAO)
Journal of Agricultural Extension

Vol.19 (1) June, 2015

ISSN 24086851

http://journal.aesonnigeria.org

http://www.ajol.info/index.php/jae

pineapples, cocoa farmers perceived such linkages to provide a platform to solve challenges or offer needed support as shown in Table 5c.

Table 5c: Purpose of farmer-to-processor linkages

\begin{tabular}{|c|c|c|c|c|c|c|c|c|c|c|c|c|}
\hline \multirow{4}{*}{ Nature of Linkage } & \multicolumn{6}{|c|}{ Cocoa } & \multicolumn{6}{|c|}{ Pineapple } \\
\hline & \multicolumn{6}{|c|}{ Purpose } & \multicolumn{6}{|c|}{ Purpose } \\
\hline & \multicolumn{2}{|c|}{$\begin{array}{l}\text { Info } \\
\text { Sharing }\end{array}$} & \multicolumn{2}{|c|}{$\begin{array}{l}\text { Solving } \\
\text { Challenges }\end{array}$} & \multicolumn{2}{|c|}{$\begin{array}{l}\text { Getting } \\
\text { Support }\end{array}$} & \multicolumn{2}{|c|}{$\begin{array}{l}\text { Info } \\
\text { Sharing }\end{array}$} & \multicolumn{2}{|c|}{$\begin{array}{l}\text { Solving } \\
\text { Challenges }\end{array}$} & \multicolumn{2}{|c|}{$\begin{array}{l}\text { Selling } \\
\text { Produce }\end{array}$} \\
\hline & Freq. & $\%$ & Freq. & $\%$ & Freq. & $\%$ & Freq. & $\%$ & Freq. & $\%$ & Freq. & $\%$ \\
\hline $\begin{array}{l}\text { Farmer-to- } \\
\text { Processor }\end{array}$ & 27 & 19 & 45 & 33 & 66 & 48 & 1 & 0.4 & 1 & 0.4 & 278 & 99 \\
\hline
\end{tabular}

Source: Fieldwork, (2011)

\section{Horizontal Linkages and Innovativeness in the Cocoa and Pineapple Value Chains}

For the pineapple value chain, the case study showed how small-scale pineapple farmers through their FBOs, had introduced demand-driven principles to market their pineapples. The basic thrust of these principles centred on pineapple farmers first looking for potential buyers, and entering into a memorandum of understanding with such buyers before planting. This way, they could be sure that a greater percentage of suckers they put in the soil would produce fruits which would be sold. One of the pineapple FBOs, the Fotobi Cooperative Pineapple Growers and Marketers Society, for instance, has a Marketing Committee which negotiates for better terms for its members. Besides, the Committee has the responsibility for exploring possible markets and facilitating the signing of Memoranda of Understanding between potential buyers and farmers who are members of the association. The Committee further monitors farmers and ensures that they meet the requirements of the market. This is consistent with the results of a similar case study of the Ugandan fishery industry, where the Ugandan Fish Processors and Exporters Association united their efforts to ensure adherence to established standards, which was one of the challenges in the industry (Kibwika et al., 2009). 
Creative Commons User Licence: CC BY-NC-ND

Abstracted by: EBSCOhost, Electronic Journals Service (EJS),

Google Scholar, Directory of Open Access Journals (DOAJ),

Journal Seek, Scientific Commons, and

Food and Agricultural Organization (FAO)
Journal of Agricultural Extension

Vol.19 (1) June, 2015

ISSN 24086851

http://journal.aesonnigeria.org

http://www.ajol.info/index.php/jae

Such farmer associations create the platform for exchange of information and sharing of experiences. The Cocoa Research Institute of Ghana (CRIG) produces a farmers' newspaper, which disseminates information on cocoa to cocoa farmers. Not all members of FBOs are literate; hence at meetings of FBOs, executives read and pass on the information in the local dialect to members who cannot read. Some of the information in the newspaper is discussed at such meeting, offering a good platform for information sharing.

There are obvious advantages of horizontal linkages for cocoa farmers; some of these advantages serve as good sources of innovativeness in the value chain. First, through cocoa FBO, farmers had improved their accessibility to modern farming technologies. It is much easier to create a platform for knowledge sharing and transfer when farmers are organised in groups, rather than individual farmers loosely knitted. This explained why the activities of the CRIG were better felt in communities where farmers were more organised. Second, input supplying shops were noted to be sparsely distributed in the communities, and were distance apart from farming communities. Consequently, door-to-door services were usually not common. Farmer groups therefore organised themselves to solicit the services of input suppliers who also used the platform for education on the correct application of inputs. Through this innovative arrangement, input supplying services had become more accessible to farmers who hitherto had to travel long distances to buy particular farm inputs. Third, banks find it more secure to grant loans to farmers in groups than individuals. The study showed that farmer groups had been used to indemnify such loans, placing greater responsibility on the groups to ensure that their members did not default to give more credibility to the groups.

Pineapple farmers' consciousness of quality issues had reflected in their desire to work towards obtaining GLOBALGAP certification. The cost of quality certification was observed to be beyond the reach of most small-scale pineapple farmers. A pineapple farmer had to pay the equivalent of about 1700 US \$ to be able to go through certification from the Kenyan-based Africert, an accredited agent of GLOBALGAP (Mensah, personal communication, 2010). Besides, as the requirements for certification, the farmer needs to go through series of training and open up his farm for inspection. The farm must be equipped with basic logistics such as first aid box, protective equipment etc. Pineapple farmers who produce on medium to large-scale basis usually have the resources to be able to afford the cost. Small-scale pineapple farmers have therefore forged linkages as a means of addressing the high cost of certification. Members of pineapple FBOs therefore pool resources together and occasionally seek support from donor agencies such as GTZ to be able to receive certification. The Ministry of Food and Agriculture (MoFA) also supports by running trainings for such farmers preparing for certification. Certification for the small-scale pineapple farmer has become a necessity in view of the requirement of GLOBALGAP from oversea buyers and commercial processing companies. The Fotobi Cooperative and Pineapple Growers and Marketers Society, for instance, is a GLOBALGAP certified outgrower of Blue Skies, a pineapple processing company, thanks to the training received by members of the 
Creative Commons User Licence: CC BY-NC-ND

Abstracted by: EBSCOhost, Electronic Journals Service (EJS),

Google Scholar, Directory of Open Access Journals (DOAJ),

Journal Seek, Scientific Commons, and

Food and Agricultural Organization (FAO)
Journal of Agricultural Extension

Vol.19 (1) June, 2015

ISSN 24086851

http://journal.aesonnigeria.org

http://www.ajol.info/index.php/jae

association from the USAID-sponsored Trade and Investment Programme for a Competitive Export Economy (TIPCEE) through the MoFA.

\section{Vertical Linkages and Innovativeness in the Cocoa Value Chain}

Vertical linkages in the cocoa value chain take two forms; first, farmers' linkages with other value chain actors such as buyers and processors, and second, farmers' linkages with service providers such as researchers, agricultural extension agents and financial institutions. Cocoa farmers' linkages with input suppliers, from the case study, were observed to be rather weak. Perhaps a good case of strong vertical linkage was the one that existed between farmers and licensed buying companies (LBCs) through their respective cocoa purchasing clerks (CPCs). Cocoa farmers could only sell to COCOBOD through LBCs, making them the first port of call with respect to the farmers. Beyond buying from farmers, the relationship occasionally offered the platform for extension service delivery, and offer of credit or inputs.

Farmer-processor linkages in the cocoa value chain were also observed to be virtually non-existent as cocoa processors did not buy directly from farmers. Cocoa processors buy their cocoa beans only from the COCOBOD through its unit, the Cocoa Marketing Company. However, in recent times, Cadbury Ghana Limited, a major international cocoa processor, is noted to be one of the first cocoa processing companies to initiate moves towards establishing linkages with cocoa farmers through the Cadbury Cocoa Partnership (CCP) established in 2008, to secure the economic, social and environmental sustainability of about a million cocoa farmers and their communities in Ghana, India, Indonesia and the Caribbean through long-term commitment to improving farmer livelihoods and farming communities and direct farmer involvement alongside NGO partners and government (http.//www.collaboration.cadbury.com).

Vertically, COCOBOD establishes linkages with farmers through some of its divisions. The CRIG, for instance, has fruitful linkages with farmers who are organised. The more organised cocoa farmers (i.e. the existence of a cocoa FBO), the more intense the activities of CRIG through periodic visits by scientists/researchers for the purpose of facilitating knowledge acquisition or technology transfer. Indeed, farmers in cocoa communities who had never interacted with officials of CRIG attributed the situation to the absence of a cocoa farmer group. Farmers explained that a resource person would find it more conducive to deliver a talk on a technology to a more organised group of cocoa farmers rather than individuals. The Peace Farmers Association, a cocoa FBO at Busosu, for instance, ha a partnership with the CRIG through which a 32-acre plot ha been acquired by the association for cocoa farming. As part of a proposal submitted by the association under the partnership, the association would be expected to buy improved cocoa pods from the CRIG to be nursed into cocoa seedlings for distribution to its members. Based on the projection of the association, 30,000 seedlings would be nursed for distribution to farmers. The CRIG, on the other hand, would adopt the farm as a demonstration farm for the purpose of training cocoa farmers. Besides, the CRIG periodically organises field days with the active participation of cocoa farmer associations, who are invited for their members to learn at firsthand new trends in the cocoa farming enterprise. 
Creative Commons User Licence: CC BY-NC-ND

Abstracted by: EBSCOhost, Electronic Journals Service (EJS),

Google Scholar, Directory of Open Access Journals (DOAJ),

Journal Seek, Scientific Commons, and

Food and Agricultural Organization (FAO)
Journal of Agricultural Extension

Vol.19 (1) June, 2015

ISSN 24086851

http://journal.aesonnigeria.org

http://www.ajol.info/index.php/jae

Generally, the COCOBOD interacts more directly and more strongly with cocoa farmers through the Cocoa Swollen Shoot Virus Disease Control Unit (CSS VDCU). In 2010, after separating cocoa extension from the unified extension system of the Ministry of Food and Agriculture (MoFA), government transferred cocoa extension to the CSSVDCU under a public-private partnership arrangement. This policy decision is likely to strengthen COCOBOD's relationship with cocoa farmers. Based on the focus group discussion sessions with cocoa farmers, there appeared to be a general sense of dissatisfaction among the cocoa farmers as regards extension delivery under the unified extension system of the MoFA. Farmers claimed some extension staff exhibited some level of bias in favour of crops other than cocoa, and the visibility of extension staff in the cocoa growing communities was rather low. The activities of the community extension agents of the CSSVDCU have included community visits, field demonstration, and facilitation of group formation. Agents have adopted the community-focused approach to extension delivery and consequently have involved the community in whatever they do (Asare Danquah, personal communication, 2010).

The Seed Production Unit (SPU) of the COCOBOD, multiplies improved cocoa varieties developed by the CRIG for distribution to farmers, and through this activity, contributes to innovation to the value chain as far as the use of improved cocoa variety is concerned. The cocoa buying activity of LBCs is contingent on the work of the Quality Control Division (QCD), which has the responsibility for inspection, grading and sealing of cocoa for the local and international market. Hence LBCs' linkages with the QCD can be described as one of the strongest relationships in the cocoa value chain. Thanks to the efforts of the $\mathrm{QCD}$, among cocoa producing countries, Ghana is reputed to produce one of the best qualities of cocoa.

A good example of vertical linkages in the cocoa value chain, which exemplifies how linkages engender innovation, is the linkage between industry and academia under the African Knowledge Transfer Partnership (AKTP). The AKTP is collaboration between the Cocoa Processing Company (CPC) Ltd and the University of Ghana under a British Council pilot project with the Association of Ghana Industries. Its objective is to help the partners involved in the project to improve their competitiveness and productivity through innovations and better use of scientific knowledge, technology and skills. The partnership involves three parties; an academic supervisor (a senior university researcher), an associate (final year university student) and a company supervisor (in this case, of the CPC). The associate serves as the link between the academic supervisor and the company supervisor through whom the technology is developed and applied. These three parties work together in a kind of 'innovation theatre' to develop a technology that when applied leads to improved efficiency of production and quality product. One of the monuments to the memory this collaboration is the development of a new brand of chocolate called 'aspire' designed and developed for diabetic patients.

\section{Vertical Linkages and Innovativeness in the Pineapple Value Chain}

Vertical linkages as in famers' interactions with other value chain actors are fairly stronger in the pineapple value chain. Commercial pineapple farmers network with their counterpart small-scale pineapple farmers through the outgrower scheme. KORANCO Farm, for instance, networks with small-scale pineapple farmers in the community under the umbrella of the KORANCO Outgrower 
Creative Commons User Licence: CC BY-NC-ND

Abstracted by: EBSCOhost, Electronic Journals Service (EJS),

Google Scholar, Directory of Open Access Journals (DOAJ),

Journal Seek, Scientific Commons, and

Food and Agricultural Organization (FAO)
Journal of Agricultural Extension

Vol.19 (1) June, 2015

ISSN 24086851

http://journal.aesonnigeria.org

http://www.ajol.info/index.php/jae

Association, which brings together over 180 small-scale pineapple farmers (Koranteng, personal communication, 2011). These outgrower farmers produce for sale to KORANCO Farm, while these small-scale farmers benefit from technology transfer from KORANCO Farm. Producerprocessor linkages in the pineapple value chain are quite strong. Generally, pineapple processors in the value chain have always maintained linkages with all categories of farmers, large-scale, medium-scale and small-scale, to guarantee their source of raw material. Such linkages are often limited to periodic visits and offer of technical advice. Blue Skies, a pineapple processing firm in the study area, for instance, has an Agronomy Department, which periodically undertakes on-farm trials with farmers to generate new knowledge.

Pineapple farmers' linkages with input suppliers, though quite strong, have largely been informal and served as platform for the offer of technical advice on the application of inputs. Producerinput supplier linkages appear more dominant with small-scale pineapple farmers. Commercial farmers deal more with importers than with retailers of agricultural inputs. Other evidence of vertical linkages involves value chain actors' interactions with support service providers such as agricultural extension agents, Non-governmental organisations, research and development institutions and certification and regulatory institutions. Farmer-extension agent linkages have been perhaps the strongest linkages with value chain actors, especially small-scale pineapple farmers. Activities of extension agents have included facilitation of farmer group formation, periodic meetings, training, field demonstration and offer of technical advice. The entry of international NGOs into the community has been facilitated by agricultural extension agents, and in most cases; trainings have been collaboratively undertaken with such agents. Non-governmental organisations and international donor agencies such as GTZ, and USAID, have played active role in helping to shape the direction of the pineapple industry, and their linkages with value chain actors, especially smallholder pineapple farmers, have been dominant and fruitful. The USAIDinitiated Trade and Investment Programme for Competitive Export Economy (TIPCEE) had carried out farmer training to build the capacity of most smallholder pineapple farmers, especially in the production of MD2. The GTZ had in the past, organised training for KORANCO Farm in the handling of agrochemicals and safety of workers on pineapple farms. These trainings have improved safety of farm workers and minimised risks (Koranteng, personal. communication, 2010).

Local research and development institutions such as the Council for Scientific and Industrial Research (CSIR) and the public universities have been good sources of technologies. However, in spite of their strategic role, value chain actors' linkages with such institutions were noted to be weak. Awareness and visibility of such institutions among small-scale pineapple farmers in the study area were observed to be rather low. While the Biotechnology and Nuclear Agricultural Research Institute of the Ghana Atomic Energy Commission had supported farmers with the supply of pineapple plantlets using its Tissue Culture facility, others such as the Food Research Institute of the CSIR had supported processors through training and conduct of chemical analysis. Processors have also benefited from the training offered by regulatory and certification agencies such as the Food and Drugs Authority and the Ghana Standards Authority. 
Creative Commons User Licence: CC BY-NC-ND

Abstracted by: EBSCOhost, Electronic Journals Service (EJS),

Google Scholar, Directory of Open Access Journals (DOAJ),

Journal Seek, Scientific Commons, and

Food and Agricultural Organization (FAO)
Journal of Agricultural Extension

Vol.19 (1) June, 2015

ISSN 24086851

http://journal.aesonnigeria.org

http://www.ajol.info/index.php/jae

\section{Cross-Case Comparison and Discussions}

The policy environment can either promote public sector leadership or private sector leadership in value chain functions and service provision depending on the nature of the influence of policy on the commodity value chain and its actors as a whole. While the cocoa value chain exhibits strong public sector leadership, there is a relatively strong private sector leadership in the activities of the pineapple value chain as shown in Table 6 below.

Table 6: Nature of leadership in the various value chain functions and support services for cocoa and pineapple

\begin{tabular}{|l|l|l|l|l|}
\hline Case study & Value chain function & $\begin{array}{l}\text { Nature of } \\
\text { leadership }\end{array}$ & \multicolumn{1}{|c|}{ Support service } & \multicolumn{1}{|c|}{$\begin{array}{c}\text { Nature of } \\
\text { leadership }\end{array}$} \\
\hline Cocoa & $\begin{array}{l}\text { Production } \\
\text { Input supplying } \\
\text { Processing } \\
\text { Marketing }\end{array}$ & $\begin{array}{l}\text { Private } \\
\text { Private- } \\
\text { public } \\
\text { Private } \\
\text { Public- } \\
\text { private }\end{array}$ & $\begin{array}{l}\text { R \& D } \\
\text { Extension } \\
\text { Pest/Disease } \\
\text { Finance }\end{array}$ & $\begin{array}{l}\text { Public (CRIG) } \\
\text { Public-private } \\
\text { Public-private } \\
\text { Private }\end{array}$ \\
& $\begin{array}{l}\text { Private } \\
\text { Private } \\
\text { Private } \\
\text { Private }\end{array}$ & $\begin{array}{l}\text { R \& D } \\
\text { Extension } \\
\text { Pest/Disease Control } \\
\text { Finance }\end{array}$ & $\begin{array}{l}\text { Private-public } \\
\text { Private-public } \\
\text { Private }\end{array}$ \\
\hline
\end{tabular}

Source: Field Work, (2011)

Note: Public-Private $=$ Public outweighs private; Private-public $=$ private outweighs public

Such private sector leadership in service provision finds expression in pineapple research and extension delivery championed by such private sector actors as commercial farmers, commercial processors, and input suppliers. Additionally, value chain functions in the pineapple value chain are chracterised by activities of more private sector actors. While marketing of fresh pineapples are exclusively private sector dominated, marketing of cocoa beans is highly public sector regulated through the activities of the state-owned COCOBOD. According to Laven (2007), Ghana remains the only cocoa producing country in the world without a fully liberalised marketing system. Generally, value chain functions in the cocoa value chain are characterised by a preponderance of public sector-led policy interventions, some of which have included the nationwide Cocoa Disease and Pest Control programme (CODAPEC), otherwise known as the mass spraying exercise initiated during the 2001/2002 cocoa season; the Cocoa Rehabilitation Scheme, to assist farmers to rehabilitate and re-plant old, destroyed and abandoned farms (MMYE, 2006). Besides, there is strong public sector leadership in service provision in the cocoa value chain reflected in the activities of the Cocoa Research Institute of Ghana, one of the divisions of 
Creative Commons User Licence: CC BY-NC-ND

Abstracted by: EBSCOhost, Electronic Journals Service (EJS),

Google Scholar, Directory of Open Access Journals (DOAJ),

Journal Seek, Scientific Commons, and

Food and Agricultural Organization (FAO)
Journal of Agricultural Extension

Vol.19 (1) June, 2015

ISSN 24086851

http://journal.aesonnigeria.org

http://www.ajol.info/index.php/jae

the COCOBOD, whose mandate is to undertake research into all problems relating to the production, processing and utilisation of cocoa, and provide information and advice on all matters relating to the production of the crop (Appiah, 2004).

Conceptually, the study defines innovativeness within the realm of a multi-dimensional, collective and interactive phenomenon where actors forge linkages for effective information sharing (Spielman et al., 2009; Hall et al., 2006; Van Huis et al., 2005; Leeuwis, 2004). The study consequently makes the assumption that the policy environment may influence the behavior, practices and the desire on the part of actors in the value chain to forge linkages, which may reflect on the way they exhibit innovativeness as depicted in figure 2.

Policy Environment

( R \& D, Extension Delivery

Macro-economic Situation)

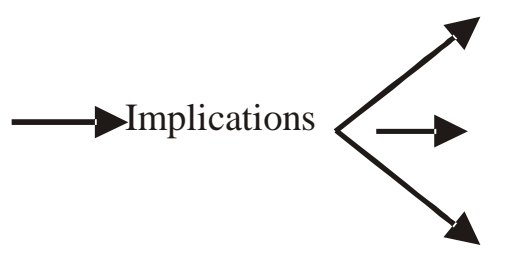

Behaviour

Practices

Linkages/

Network

Interactions

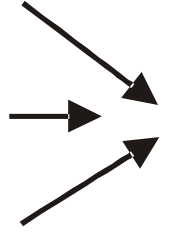

Innovativeness

(Capacity to Respond

to Challenges)

Figure 2: Model representing relationship between the policy environment (with its influence on behaviours, practices and linkages/network/interactions among actors) and innovativeness of value chain actors. Source: Fieldwork 2011

The case studies showed that the stronger the linkages in a value chain, the more likely actors exhibited the propensity to exhibit innovativeness. Generally the study showed stronger value chain linkages in the pineapple value chain than the cocoa value chain. For instance, from the survey of small-scale farmers, while $90 \%$ of pineapple farmers in the study area claimed to have linkages with pineapple processors, processor-producer linkages in the cocoa value chain was $42 \%$. Similarly, while $83 \%$ of small-scale pineapple farmers in the study area claimed linkages with input suppliers, that for small-scale cocoa farmers stood at $43 \%$. Consequently, there was more preponderance of innovative activities among pineapple farmers than cocoa farmers. When cocoa farmers were asked in the survey if they remembered the last time they had employed new ideas to improve their farming enterprise, half of them answered in the affirmative. Meanwhile, $80 \%$ of pineapple farmers claimed to have applied new ideas in agronomy. There was no evidence of innovative activities in marketing among cocoa farmers as the policy environment provided public sector leadership in that enterprise, reducing the inclination on the part of cocoa farmers to forge linkages with buyers. However, $78 \%$ of small-scale pineapple farmers in the study area claimed to have implemented new ideas in marketing especially through their FBOs.

Blue Skies, one of the pineapple processing firms in the study area has an Agronomy Unit, and agronomists in this Unit undertake on-farm trials with small-scale pineapple farmers in the area to 
Creative Commons User Licence: CC BY-NC-ND

Abstracted by: EBSCOhost, Electronic Journals Service (EJS),

Google Scholar, Directory of Open Access Journals (DOAJ),

Journal Seek, Scientific Commons, and

Food and Agricultural Organization (FAO)
Journal of Agricultural Extension

Vol.19 (1) June, 2015

ISSN 24086851

http://journal.aesonnigeria.org

http://www.ajol.info/index.php/jae

generate packages to address production challenges of famers. This exemplifies how farmerprocessor linkages in the pineapple value chain can engender innovativeness. Similarly, in the cocoa value chain, the African Knowledge and Transfer Partnership exemplifies how linkages between academia and a cocoa processor can translate into innovative activities.

The mobile phone as an ICT tool served as a facilitator of linkages and a medium for the exchange of innovative ideas especially among farmers. However, while its penetration among small-scale pineapple farmers according to the survey was $95 \%$, in the case of small-scale cocoa farmers, its penetration was $27 \%$.

\section{Conclusion and Policy Implications}

The study showed that a policy environment that promoted public sector leadership in value chain functions and service provision, tended to offer less incentives for smallholder producers in the value chain to forge linkages and interact horizontally (among themselves) or vertically (with other value chain actors and service providers). It demonstrated how linkages among actors in agricultural commodity value chains could translate into innovative activities and enhance the capacity of actors to respond to challenges in the industry. It concluded that actors in agricultural value chain can build their capacity to respond to challenges if they united their efforts. In terms of policy implication, the study makes a case for more private sector involvement in value chain functions and service provision as it is more likely to foster linkages towards systems innovation.

\section{Acknowledgements}

The authors are very grateful to the Director, Research, Monitoring and Evaluation, Ghana Cocoa Board Head Office, the Head of the Cocoa Swollen Shoot Virus Control Unit of the Ghana Cocoa Board at Tafo and staff of the Akuapem South District Office of the Ministry of Food and Agriculture for the support in carrying out the study. We are thankful to all the agricultural extension agents in the two districts who invested their time in the administration of the questionnaires. Lastly, we are indebted to the Council for Scientific and Industrial Research for funding the study. This paper is published by the kind permission of the Council.

\section{References}

Appiah, M. R. (2004). Impact of Cocoa Research Innovations on Poverty Alleviation in Ghana. Ghana Academy of Arts and Sciences, August 2004.

Ahenkorah, Y., Halm, B. J., Appiah, M. R. (1987). Twenty years' results from shade and fertilizer trial on Amazon Cocoa in Ghana. Exp Agric 23:31-39

Appiah, M. R., Ofori-Frimpong, K., Afrifa, A. A., Asante, E. G. (1997). Prospects of Fertilizer Use in the Cocoa Industry in Ghana. Proceedings, Soil Science society of Ghana 14 \& $15: 216-221$ 
Creative Commons User Licence: CC BY-NC-ND

Abstracted by: EBSCOhost, Electronic Journals Service (EJS),

Google Scholar, Directory of Open Access Journals (DOAJ),

Journal Seek, Scientific Commons, and

Food and Agricultural Organization (FAO)
Journal of Agricultural Extension

Vol.19 (1) June, 2015

ISSN 24086851

http://journal.aesonnigeria.org

http://www.ajol.info/index.php/iae

Bailey, J. F. \& C. M. Ford (2003). Innovation and Evolution : Managing Tensions Within and Between Domains of Theory and Practice: In L. V. Shavinnina(ed) The International Handbook on Innovation pp 248-257 Oxford: Elsever Science Limited

Biggs, S. D. (1989). Resource-poor Farmers' Participation in Research Impact of Cocoa Research: A Synthesis of Experiences from Nine Agricultural Research Systems. OFCOR Comparative Study Paper No. 3 ISNAR

Business Council of Australia (2006). New Concepts in Innovation: The Keys to a Growing Australia, BCA

Campbell, J. \& Salagrama, V. (2000). New Approaches to Participation in Fisheries Research: A Discussion Document Commissioned by the FAO and SIFAR

Chambers, R., Pacey, A. \& Thrupp, L. (eds) (1989). Farmer First Farmer Innovation and Agricultural Research. Intermediate Technology Publications, London, 423 pp.

Chambers, R. \& Jiggins, J. . (1987). Transfer of technology and farming systems research. Agricultural Administration and Extension 27: 35-52

COCOBOD (2007). "Editorial-Efforts to Combat Child Labour in the Cocoa Sector" COCOBOD News Vol 3, Issue 3, December 2007 p. 3

Hall, A., Janseen, W., Pehu, E., \& Rajalahti, R. (2006). Enhancing Agricultural Innovation; How to Go Beyond the Strengthening of Research Systems. World Bank, Washington DC

Hayami, Y. \& Rattan, M.. (1985). Agricultural Development: An International Perspective. John Hopkins University Press, Baltimore

Kibwika, P., Kyazze, F. B. \& Nassuma-Musoke, M. C : (2009). How Public Policies Enhance or Impede Agribusiness Innovation: A Study of Fish, Banana and Vegetable Value Chains in Uganda. Study Commissioned by the Government of Denmark and the World Bank Institute.

Kotler, P. \& Anderson, A. R. (2003). Strategic Marketing for Non-Profit Organisation. Upper Saddle River, New York

Laven, A. (2007). Marketing reforms in Ghana's Cocoa Sector: Partial Liberalisation, Partial Benefits? Background Notes. Oversea Development Institute (Odi) 
Creative Commons User Licence: CC BY-NC-ND

Abstracted by: EBSCOhost, Electronic Journals Service (EJS),

Google Scholar, Directory of Open Access Journals (DOAJ),

Journal Seek, Scientific Commons, and

Food and Agricultural Organization (FAO)
Journal of Agricultural Extension

Vol.19 (1) June, 2015

ISSN 24086851

http://journal.aesonnigeria.org

http://www.ajol.info/index.php/iae

Leeuwis, C. (2004). Communication for Rural Innovation-Rethinking Agricultural Extension. Blackwell Science, Oxford

Lundvall, B. A. (ed) (1992). National Systems of Innovation and Interactive Learning. London, UK, Pinter, 161 pp.

Miller, R. L. \& Cox, L (2006). Technology Transfer Preferences of Researchers and Producers in Sustainable Agriculture. Journal of Extension Vol 44, No. 3, Article No. 3R1B3

Ministry of Manpower, Youth and Employment (MMYE) (2006). Labour Practices in Cocoa Production in Ghana (Pilot Survey) National Programme for the Elimination of Worst Forms of Child Labour in Cocoa (NPEWFCLC) Ministry of Manpower, Youth and Employment, Accra, Ghana

Nederlof, E. S.(2006). Research on Agricultural Research: Towards a pathway for clientoriented research in West Africa. Published PhD dissertation, Wageningen University, Wageningen, The Netherlands

Natural Resources Institute (NRI) (2009). Ghana Export Horticulture Cluster Strategic Profile Study Document prepared by the Natural Resources Institute for the World Bank Sustainable Development Network (WB-SDN), Africa Report, Agriculture and Rural Development (AFTAR). The Republic of Ghana, Ministry of Food and Agriculture and the European Union. All ACP Agricultural Commodities Programme.

Rajalahti, R., Janssen, W. and Pehu, E. (2008). Agricultural Innovation Systems: From Diagnostic Towards Operational Practices Agricultural and Rural Development Discussion Paper 38, World Bank, Washington DC, USA

Rogers, E. (2003). Diffusion of Innovation. $5^{\text {th }}$ edition, Free Press.

Roling N.G.(2010). Banana (Musa spp) and New Thinking About Pathways for Science Impact. ISHS Acta Horticulture 879

Roling, N. G., Hounkonnou, D., Offei, S. K., Tossou, R. \& Van Huis, A. (2004). Linking science and farmers' innovative capacity: Diagnostic studies from Ghana and Benin. NJAS Vol 52 Nos 3-4, December 2004, pp 209-448

Roseboom, J. (2004). Adopting an Agricultural Innovation Systems Perspective: Implication for ASARECA;s Strategy Planning Paper No. 7 
Creative Commons User Licence: CC BY-NC-ND

Abstracted by: EBSCOhost, Electronic Journals Service (EJS),

Google Scholar, Directory of Open Access Journals (DOAJ),

Journal Seek, Scientific Commons, and

Food and Agricultural Organization (FAO)
Journal of Agricultural Extension

Vol.19 (1) June, 2015

ISSN 24086851

http://journal.aesonnigeria.org

http://www.ajol.info/index.php/jae

Spielman, D. J., Ekboir, J. \& Davis, K. (2009). The art and science of innovation systems inquiry: applications to Sub-Saharan African agriculture. Technology in Society 31, $399-405$

World Bank (2006). Enhancing Agricultural Innovation: How to Go Beyond the Strengthening of Research Systems. Washington DC, World Bank 